\title{
PEMBERDAYAAN PENGRAJIN MELALUI INOVASI PRODUK "REMITAN" RAMAH ANAK BERDAYA SAING GLOBAL DI KAMPOENG REMITAN DESA MAYONG LOR, KABUPATEN JEPARA, JAWA TENGAH
}

\author{
Jayanti Putri Purwaningrum ${ }^{1}$, Imaniar Purbasari ${ }^{1}$, dan Gilang Puspita Rini ${ }^{2}$ \\ ${ }^{1}$ Fakultas Keguruan dan Ilmu Pendidikan, Universitas Muria Kudus \\ ${ }^{2}$ Fakultas Ekonomi dan Bisnis, Universitas Muria Kudus \\ Email : jayanti.putri@umk.ac.id
}

\begin{abstract}
ABSTRAK
Desa Mayong Lor Kecamatan Mayong Kabupaten Jepara merupakan desa sentra kerajinan tanah liat "Remitan". Remitan merupakan mainan anak tradisional dari tanah liat berupa miniatur alat dapur seperti wajan, cobek, muntu, tungku, gentong, piring, dan lain-lain. Saat ini, pengembangan remitan sebagai produk unggulan daerah belum berkembang secara optimal oleh Dinas Perindustrian dan Perdagangan serta UMKM di Jepara. Permasalahan yang dialami mitra saat ini adalah tidak adanya ragam produk "remitan" yang ramah anak. Metode yang digunakan dalam pengabdian kepada masyarakat pada UKM Kampoeng Remitan yakni melalui sosialisasi, forum group discussion (FGD) dan workshop. Hasil dari kegiatan ini adalah adalah 1) pengetahuan pengrajin remitan tentang produk ramah anak meningkat dan 2) mitra memiliki pengetahuan dan keterampilan dalam membuat inovasi produk "remitan" berbasis ramah anak.
\end{abstract}

Kata Kunci: remitan, gerabah, inovasi produk

\section{PENDAHULUAN}

Jepara merupakan kabupaten di provinsi Jawa Tengah yang memiliki banyak potensi lokal sentra industri yang berkembang. Sentra industri yang paling terkenal di Jepara adalah ukir dan mebel. Industri lain yang ada di Jepara adalah monel, tenun troso, anyaman rotan, dan kerajinan tanah liat. Pada dasarnya sentra-sentra industri di Kabupaten Jepara memiliki beragam produk lokal yang dapat diperdagangkan ke mancanegara. Namun kenyataannya, tidak semua sentra industri tersebut menjadi primadona unggulan yang menjadi pusat konsentrasi ekonomi di Kabupaten Jepara, salah satunya adalah sentra industri yang berada di Desa Mayong Lor, Kecamatan Mayong, Jepara. Desa Mayong Lor merupakan sebuah desa di Kecamatan Mayong, Jepara yang secara historis terkenal sebagai daerah sentra industri seni kerajinan tanah liat seperti kendi, celengan dan remitan. Tanah liat jenis earthenwerwe (siap digunakan) merupakan potensi alam wilayah setempat, dikreasikan dengan nilai estetis dan budaya menjadi jenis 
keramik bakaran rendah yang menyokong kebutuhan masyarakat pedesaan yang mengandung nilai ekonomi, sosial, budaya, pendidikan dan lingkungan.

Hampir semua warga desa berprofesi sebagai pengrajin tanah liat. Komunitas masyarakat pendidikan menengah mengandalkan hasil proses produksi dan distribusi sebagai roda ekonomi. Eksistensi industri seni kerajinan tanah liat di Desa Mayong Lor selain menghasilkan karya seni yang bernilai estetis juga telah menjadi identitas budaya serta sumber ekonomi desa dan warga masyarakatnya antar generasi[1]. Hal ini sesuai dengan faktor kebudayaan masyarakat Desa Mayong Lor yakni masyarakat pesisir dimana sebagian besar hidupnya menggantungkan pada pengelolaan potensi perdagangan dan industri[2].

Adapun produk unggulan dari Desa Mayong Lor adalah remitan. Remitan merupakan mainan anak tradisional dari tanah liat yang berupa miniatur alat dapur seperti wajan, cobek, muntu, tungku, gentong, kendi, piring dan lain-lain yang membutuhkan biaya produksi yang relatif murah dan dibuat secara tradisional. Kerajinan tanah liat"remitan" dari Desa Mayong
Lor memiliki kekhasan dibanding dengan daerah lain yakni pembuatannya yang secara langsung dikerjakan dengan tangan, memiliki nilai estetika dari bentuknya yang praktis dan tidak rumit serta dicat dengan warna yang meriah. Nilai estetika kesederhaan kerajinan tanah liat remitan terletak pada kreativitas artistik sesuai dengan cita rasa kebudayaan penciptanya namun mampu memenuhi selera pasar.

Remitan merupakan mainan tradisional anak yang merupakan warisan nenek moyang desa Mayong Lor Jepara yang memiliki nilai tuntunan budaya, kesederhanaan, kebersamaan dan keberagaman. Dengan demikian, remitan merupakan salah satu permainan tradisional yang memiliki kekayaan khasanah budaya lokal, dan sudah seharusnya dapat dimanfaatkan dalam pembelajaran pendidikan berkarakter bangsa. Oleh karena itu, permainan tradisional masih perlu dikembangkan di zaman yang semakin maju ini, karena dapat menjadi alternatif untuk mengenalkan keberagaman budaya yang ada di Indonesia, serta dapat menanamkan nilai dan moral sebagai dasar yang membentuk pribadi anak yang luhur.

Namun demikian, produk 
unggulan mainan tradisional dari Desa Mayong Lor yakni remitan saat ini mulai tersisihkan oleh permainan modern yang sekarang lebih digemari oleh anak-anak. Hal ini mengakibatkan generasi muda dari Desa Mayong Lor yang seyogyanya menjadi penerus usaha remitan enggan meneruskan usaha tersebut. Padahal, usaha remitan memiliki potensi besar untuk dikembangkan sebab produk tersebut memiliki keunikan yang khas.

Permasalahan lain yang dialami oleh pengrajin diantaranya adalah mutu bahan baku yakni pewarna yang digunakan bukanlah pewarna yang ramah anak. Berdasarkan wawancara dengan beberapa pengrajin diperoleh hasil bahwa pewarna yang digunakan berupa cat acrylic, pigmen yang dicampur cat tembok dan tanah merah yang tidak aman untuk anak. Begitu pula bahan pengkilap produk menggunakan damar yang dicampur dengan bensin yang tidak ramah anak.

Berdasarkan masalah di atas, maka diperlukan inovasi produk remitan dengan pewarna yang ramah anak yang berdaya saing global. Hal ini dikarenakan inovasi produk merupakan kunci keberhasilan produk untuk dapat bertahan di pasar. Hamdan (2018) berpendapat bahwa era revolusi industry 4.0 memberikan pengaruh yang besar pada bidang ekonomi dan lainnya dimana banyak peluang usaha dan UKM untuk berkembang secara pesat. Hal ini sejalan dengan pendapat Wongsanukjaroen (2015) yang berpendapat bahwa inovasi produk merupakan factor utama dalam peningkatan bisnis. Apalagi kerajinan yang berasal dari tanah liat merupakan kekayaan ragam budaya Indonesia yang memerlukan terobosan produk yang berdaya saing global. Hal inilah yang menjadikan masyarakat yang mewarisi tradisi nenek moyang dalam membuat kerajinan tersebut harus dapat berkreasi dan menjadikannya sebagai andalan sumber penghasilan (Margana dan Aliyah, 2014).

Solusi inovasi produk remitan dengan pewarna yang ramah anak dilakukan dengan konsep pemberdayaan kemampuan dan keterampilan pengrajin. Hal ini sesuai dengan pernyataan Basuki dkk (2020) yang menyatakan bahwa adanya pemberdayaan dapat memberikan kesadaran masyarakat terhadap adanya peluang baru untuk peningkatan kesejahteraan hidup dan kemandirian dalam bisnis. Sulastini (2017) 
menambahkan bahwa kemampuan dalam menciptakan pengetahuan baru yang berkesinambungan melalui tindakan kreatif dan inovatif juga dapat menciptakan berbagai peluang bisnis.

Kegiatan pengabdian pada masyarakat yang dilakukan bertujuan untuk 1) memberikan pengetahuan kepada pengrajin remitan tentang produk ramah anak meningkat dan 2) memberikan pengetahuan dan keterampilan kepada pengrajin remitan dalam membuat inovasi produk "remitan" berbasis ramah anak melalui sosialisasi dan workshop; 3) Meningkatnya kualitas produk kerajinan remitan sebagai basis ekonomi masyarakat melalui capacity building pelaku usaha remitan.

\section{METODE PELAKSANAAN}

Metode yang digunakan dalam pengabdian kepada masyarakat ini adalah sebagai berikut.

\section{Sosialisasi}

Tim pengabdian melakukan kegiatan sosialisasi penggunaan alternatif pewarna dan pengkilap yang aman dan ramah anak. Kegiatan ini dilakukan satu kali pada bulan Juni 2020. Kegiatan sosialisasi dilakukan dengan cara ceramah yang selanjutnya dilakukan tanya jawab. Adanya metode tanya jawab merupakan suatu upaya dalam penyampaian materi pelatihan yang dilakukan dengan tujuan memberikan kejelasan informasi dan pengetahuan dengan cara mengajukan pertananyaan untuk dijawab pemateri.

2. Forum Group Discussion (FGD)

Tim dan mitra melakukan FGD setelah dilakukannya kegiatan sosialisasi untuk menentukan alternative pewarna yang disesuaikan dengan perbaikan produk. Kegiatan ini dilakukan satu kali pada bulan Juni 2020. Kegiatan ini melibatkan mitra untuk membahas dan memecahkan permasalahan inovasi produk remitan yang ramah anak sehingga ada kegiatan saling bertukar pikiran terkait ide dan gagasan masingmasing untuk kemudian melahirkan kesepakatan bersama

3. Workshop inovasi produk gerabah. Kegiatan workshop inovasi produk gerabah di UKM Kampung Remitan dilakukan satu kali pada bulan Juni 2020 dan dua kali pada bulan Juli 2020. kegiatan yang 
dilakukan yakni mitra secara langsung praktik membuat inovasi produk gerabah.

\section{HASIL DAN PEMBAHASAN}

Berikut hasil dari kegiatan pengabdian kepada masyarakat di UKM Kampung Remitan, Desa Mayong Lor, Jepara.

\section{Sosialisasi dan Forum Group Discussion (FGD) penggunaan alternatif pewarna dan pengkilap yang aman dan ramah anak}

Kegiatan ini diikuti oleh lima pengrajin dimana kemampuan pengrajin di UKM Kampung Remitan beragam. Dari kegiatan ini, mitra mendapatkan tambahan pengetahuan dan keterampilan dalam rangka meningkatkan inovasi produk remitan pada tahap finishing product. Adapun alternatif pewarna dan pengkilap yang dijadikan solusi dari permasalan mitra adalah oxid titan. Dimana warna-warna yang dihasilkan bergantung dari persentase atau formula pencampuran oxid titan dengan tanah liat. Oxid titan tersebut digunakan sebelum remitan dibakar ke dalam tungku botol (tungku pembakaran remitan. Perpaduan warna antara oxid titan dan tanah liat tidaklah semencolok dan semeriah pewarna acrylic dan zat tembok. Warna-warna yang dihasilkan lebih ke warna-warna soft. Namun, warna-warna tersebut justru menjadikan remitan menjadi produk berkelas dan berdaya saing global.

Pada kegiatan ini dibahas pula bahwa nyatanya produk remitan sebelum diadakannya pendampingan tidaklah aman jika dimainkan oleh anak-anak. Bahkan penggunaan pewarna-pewarna yang berbahaya tersebut dapat memiliki efek samping yang negatif di kemudian hari.

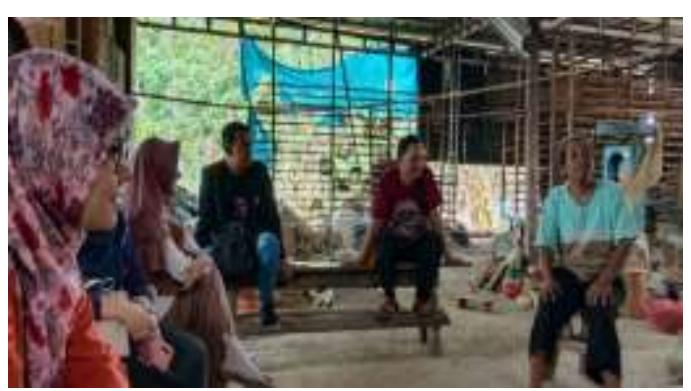

Gambar 1. Kegiatan Sosialisasi

\section{Workshop inovasi produk remitan ramah anak}

Pada kegiatan ini, secara bersama-sama tim pengabdi dan mitra melakukan praktik pembuatan produk remitan. 


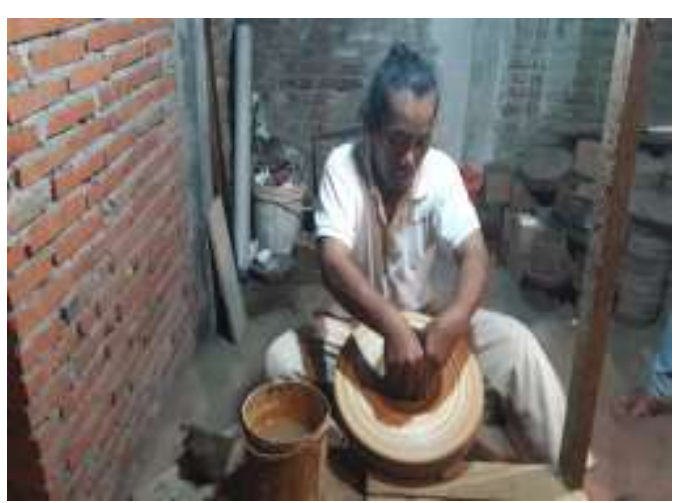

Gambar 2 Workshop Inovasi Produk

Dari kegiatan ini, pengrajin memiliki kemampuan dalam menghasilkan produk remitan dengan desain yang lebih menarik dan aman dimainkan oleh anak. Berikut perbedaan produk sebelum dan sesudah dilakukan pengabdian.

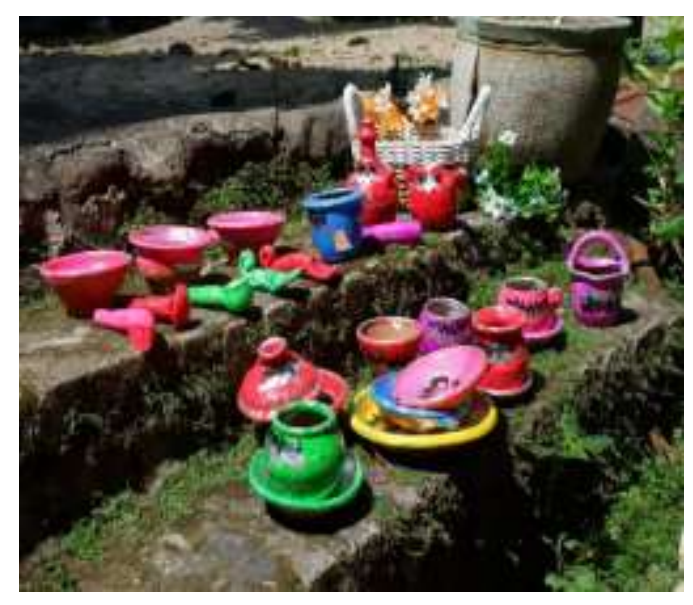

Gambar 3 Produk Remitan sebelum Adanya Pendampingan

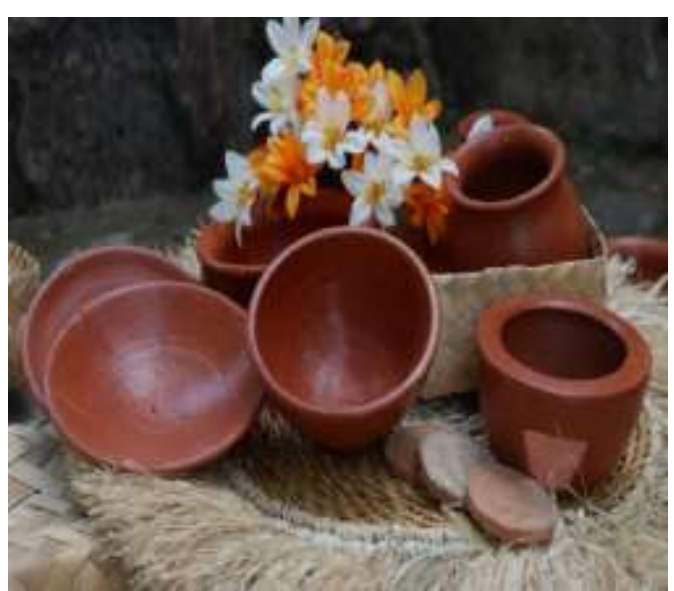

Gambar 4 Produk Remitan sebelum Diwarnai dengan Oxid Titan dan Dibakar

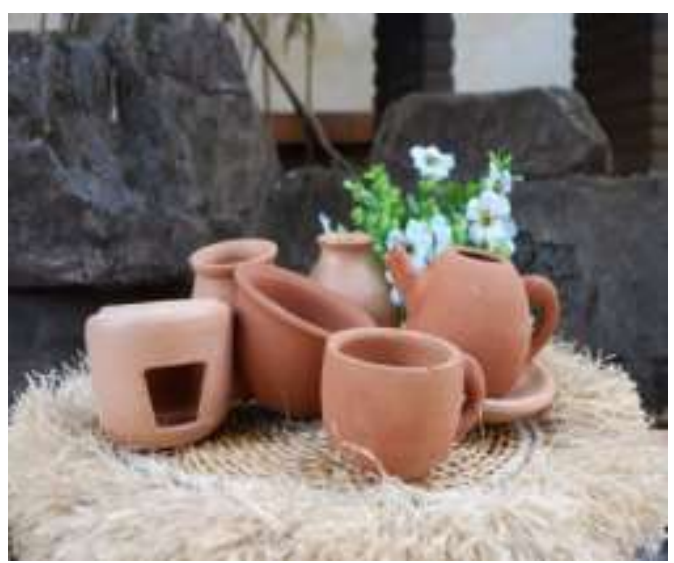

Gambar 5 Produk Remitan setelah Diwarnai dengan Oxid Titan dan sebelum dilakukan Proses Pembakaran 

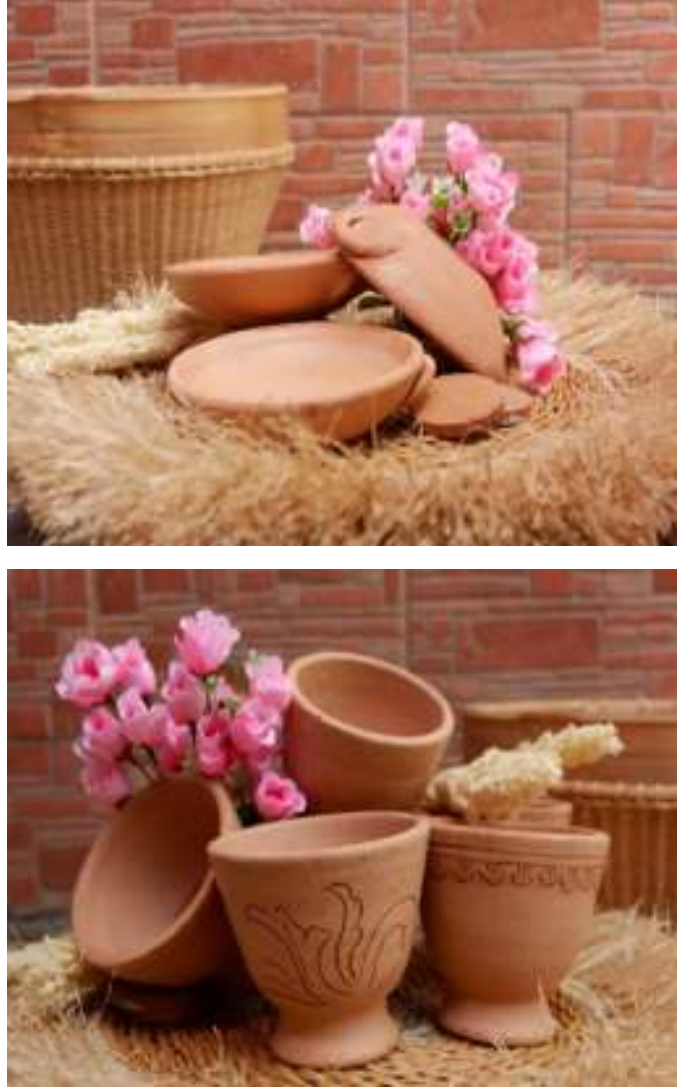

Gambar 6 Produk Remitan setelah Diwarnai dengan Oxid Titan dan dan dilakukan Proses Pembakaran

\section{KESIMPULAN}

Kegiatan Program Pengabdian pada Masyarakat kolaborasi antara Universitas Muria Kudus dan UKM Kampoeng Remitan menghasilkan peningkatan pengetahuan dan keterampilan pengrajin remitan tentang produk remitan ramah anak. Dari kegiatan yang dilakukan, secara tidak langsung terjadi peningkatan pengembangan kualitas sumber daya mitra dalam hal pewarnaan dan finishing yang mendukung ke arah peningkatan keterampilan pengrajin untuk dapat menghasilkan produk remitan berdaya saing tinggi.

Dari kegiatan ini disarankan adanya kegiatan pengabdian pada masyarakat lanjutan sebagai solusi bagi pengrajin remitan di tahun selanjutnya diantarnya dalah pemberian produk teknologi tepat guna maupun manajemen dan pemasaran usaha berbasis online. Di samping itu, hendaknya pengrajin remitan Desa Mayong Lor dapat menggunakan pengetahuan dan keterampilan yang diterima sehinga dapat meningkatkan kemampuan dalam membuat produk remitan ramah anak lain yang inovatif yang pada akhirnya meningkatkan produktivitas dan daya saing global.

\section{UCAPAN TERIMAKASIH}

Tim pengabdi dari Universitas Muria Kudus mengucapkan terimakasih kepada Kementerian Riset dan Teknologi/ Badan Riset dan Inovasi Nasional yang telah memfasilitasi dana kegiatan pengabdian kepada masyarakat melalui skim PPPUD dengan nomor 104/SP2H/PPM/DRPM/2020, tanggal 16 Maret 2020. Ucapan terimakasih juga kami ucapkan kepada LPPM Universitas Muria Kudus yang telah 
memfasilitasi program pengabdian sehingga dapat berjalan dengan baik dan lancar.

\section{DAFTAR PUSTAKA}

Basuki, Vitria A., dan Susiladewi. 2020. Memberdayakan Masyarakat Desa Melalui Pemberian Ketermapilan dan Pendampingan Perubahan Sikap. Jurnal Pengabdian Al-Ikhlas. Vol 5 No 2 hal 182-187

Hamdan, H. 2018. Industri 4.0: Pengaruh Revolusi Industri Pada Kewirausahaan Demi Kemandirian Ekonomi. Jurnal Nusantara Aplikasi Manajemen Bisnis, Vol 3 No 2

Hendro, E. P. 2000. Ketika Tenun Mengubah Desa Troso. Semarang: Penerbit Bendera

Mahbub, J. 2010. "Perkembangan Industri Kerajinan Keramik dan Peranannya terhadap Kehidupan Sosial Ekonomi Masyarakat Desa Mayong Lor Jepara Tahun 1980-
2005. Skripsi. Universitas

Diponegoro. Diakses pada

eprints.undip.ac.id/3421

Margana dan Aliyah, I. 2014. IbM

Kelompok Pengrajin Gerabah

Melalui Pengembangan Desain,

Alat Produksi dan Manajemen

Pemasaran di Kabupaten Klaten.

Journal of Rural and

Development. Vol V No 1

Februari 2014, hal 27-34

Sulastini, Ariefahnoor D., dan Surya, A. 2017. Penyusunan Pelatihan Orientasi Kewirausahaan bagi Pengrajin Figura Bingkai Kayu Jati RizkyMartapura. Jurnal Pengabdian Al-Ikhlas.Vol 2 No 2 hal 61-67

Wongsansukjaroen; Jedsada And, W. B. (2015). The Impact of Knowledge Management (KM) and Innovation on Business Performance: A Case Study of Banking Industry in Thailand. International Journal of Arts \& Sciences, Vol 8 No 1, page 317 32 